\title{
QUANTITATIVE EVALUATION OF LISTERIA MONOCYTOGENES IN FRESH AND PROCESSED SURUBIM FISH (PSEUDOPLATYSTOMA SP)
}

\author{
Souza, V.M. de ${ }^{1}$; Alves, V.F. ${ }^{1}$; Destro, M.T. ${ }^{2}$; De Martinis, E.C.P. ${ }^{1 *}$ \\ ${ }^{1}$ Faculdade de Ciências Farmacêuticas de Ribeirão Preto, Universidade de São Paulo, Ribeirão Preto, SP, Brasil; ${ }^{2}$ Faculdade de \\ Ciências Farmacêuticas, Universidade de São Paulo, São Paulo, SP, Brasil.
}

Submitted: August 22, 2007; Approved: July 09, 2008.

\begin{abstract}
L. monocytogenes is a foodborne psychrotrophic bacterial pathogen of special importance for minimally processed foods. In this work, it was enumerated in samples of surubim fish by MPN technique. The population of L. monocytogenes was estimated as $<0.012 \mathrm{MPN} / \mathrm{cm}^{2}$ in fresh and $<0.03 \mathrm{MPN} / \mathrm{g}$ in minimally processed fish.
\end{abstract}

Key-words: Listeria monocytogenes, MPN, fish, surubim

There is an increasing demand for fresh refrigerated readyto-eat (RTE) foods and the microbiological criteria for international trading have been very strict. L. monocytogenes is an important psychrotrophic foodborne pathogen, which causes listeriosis, a disease with low incidence rate $(0.1$ to 11.3 cases per million of population), but responsible for the majority of deaths due to bacterial pathogens in the US (28\%). It was implicated in several recalls of products last year (FSIS, 2007) and despite increased awareness on the risks of the disease, Koch and Stark (2006) reported that in German the number of listeriosis cases raised from 217 cases in 2001 to 519 cases in 2005 and stated that reasons for this increase remained unclear.

The disease caused by Listeria monocytogenes can manifest with mild flu-like symptoms, gastroenteritis or even lifethreatening infection, depending on the number of bacterial cells, the host susceptibility and the virulence of the strain. Although no outbreaks reported have been linked to consumption of fish, this kind of food was already incriminated in sporadic cases of listeriosis (Destro, 2000). According to Lyytikäinen et al. (2006), at least one quarter of cases of listeriosis occurred in Finland during 1995-2004 were caused by certain sero-genotype or closely related genotypes which had also been found in vacuumpacked cold smoked or cold-salted fish products.

Minimally processed fish may support listerial growth even when stored under proper conditions. The aim of this work was to determine the population of L. monocytogenes in surubim, a Brazilian fish which may be consumed after minimal processing and cold storage.

L. monocytogenes was enumerated in 33 samples of surubim fish (Pseudopatystoma sp), collected between August 2004 and June 2005. Nineteen samples of fresh eviscerated surubim fish and 14 samples of vacuum-packed smoked sliced surubim fish ( 7 within $24 \mathrm{~h}$ of processing and 7 after 35 days of storage at $5^{\circ} \mathrm{C}$ ) were analyzed. The method of Pagotto et al. (2002) was used combined with the most probable number technique, MPN (Peeler, 1992).

For that, $50 \mathrm{~g}$ of each sample of sliced fish was mixed with $450 \mathrm{ml}$ of Listeria Enrichment Broth (LEB; UVM2, CM0863, and SR 0142, Oxoid, Basingstoke, UK) and transferred to series of three tubes to contain 10, 1, 0.1, and $0.01 \mathrm{~g}$. For whole eviscerated fishes, samples were obtained by swabbing 5 different parts of each fish $\left(5\right.$ times $\left.25 \mathrm{~cm}^{2}\right)$ : three swabs from external and two swabs from inner surfaces. The swabs were placed in $50 \mathrm{ml}$ saline $(0.85 \%$ sodium chloride, $\mathrm{w} / \mathrm{v})$ and the suspension was mixed with $450 \mathrm{ml} \mathrm{LEB}$. This broth was used to prepare series of three tubes for MPN: $100 \mathrm{ml}\left(25 \mathrm{~cm}^{2}\right), 10 \mathrm{ml}\left(0.25 \mathrm{~cm}^{2}\right), 1 \mathrm{ml}(0.025$ $\left.\mathrm{cm}^{2}\right)$, and $0.1 \mathrm{ml}\left(0.0025 \mathrm{~cm}^{2}\right)$. Inoculated LEB was incubated at $30^{\circ} \mathrm{C}$ for $24 \mathrm{~h}$, when $0.1 \mathrm{ml}$ of each tube was transferred to secondary enrichment in Fraser broth (CM 895 and SR 156, Oxoid) and incubated at $35^{\circ} \mathrm{C}$ for $48 \mathrm{~h}$. From each blackened

*Corresponding Author. Mailing address: Faculdade de Ciências Farmacêuticas de Ribeirão Preto - Universidade de São Paulo, Av. do Café s/n, Ribeirão Preto, SP, Brasil, ZIP 14040-903. Tel.: +55 16 36024267, Fax: +55 16 36024725. E-mail: edemarti@usp.br 
Fraser tube, an aliquot was surface plated on Oxford (CM 0856 and SR 0206, Oxoid) and PALCAM (CM 0877 and SR 0150, Oxoid) agar plates for isolation of colonies. Up to three colonies were selected and submitted to classical methods for identification of Listeria species (Pagotto et al., 2002), combined with API Listeria (bioMérieux, Marcy l'Etoile, France).

The MPN method used in this work could detect populations of $L$. monocytogenes as low as $0.03 \mathrm{MPN} / \mathrm{g}$ of processed fish and $0.012 \mathrm{MPN} / \mathrm{cm}^{2}$ of raw whole fish. Although laborious and time consuming, the MPN technique is still currently the method of choice for quantification of levels of $L$. monocytogenes below $100 \mathrm{CFU}$ per gram (De Martinis et al., 2007). A method for enumeration of $L$. monocytogenes that is at the same time easy to perform, sensitive, specific, rapid and not expensive is not available and the isolation of $L$. monocytogenes from highly contaminated matrices depends on the capability of the method to promote growth of low number of cells potentially injured and to minimize growth of accompanying microbiota (Ingianni et al., 2001, Ryser; Donelly, 2001).

In this work, Listeria sp was not detected in any sample analyzed and the population of $L$. monocytogenes was estimated to be less than $0.012 \mathrm{MPN} / \mathrm{cm}^{2}$ in the fresh fish and less than $0.03 \mathrm{MPN} / \mathrm{g}$ in processed surubim. This data indicate the low risk of smoked sliced surubim in disseminating $L$. monocytogenes to consumers.

For risk analysis, quantitative date on foodborne pathogens is essential and our results contribute with quantification of $L$. monocytogens in RTE fish from Brazil.

\section{ACKNOWLEDGEMENTS}

This research was supported by Fundação de Amparo à Pesquisa do Estado de São Paulo, Brazil (FAPESP process \# 03/ 05764-7) and V.F. Alves is grateful to National Council for Scientific and Technological Development (CNPq), Brazil for a Ph.D. fellowship.

\section{RESUMO}

\section{Avaliação quantitativa de Listeria monocytogenes em surubim (Pseudoplatystoma sp) fresco e processado}

L. monocytogenes é um patógeno psicrotrófico transmitido por alimentos, de importância especial para alimentos minimamente processados. Neste trabalho, a bactéria foi enumerada em amostras de peixe surubim utilizando-se a técnica do NMP. A população de L. monocytogenes foi estimada como $<0.012 \mathrm{NMP} / \mathrm{cm}^{2}$ do peixe fresco e $<0.03 \mathrm{NMP} / \mathrm{g}$ do peixe minimamente processado.

Palavras-chaves: Listeria monocytogenes, NMP, peixe, surubim

\section{REFERENCES}

1. Alves, V.F.; De Martinis, E.C.P.; Destro, M.T.; Fonnesbech-Vogel, B.; Gram, L. (2005). Antilisterial activity of a Carnobacterium piscicola isolated from Brazilian smoked fish (Surubim [Pseudoplatystoma sp.]) and its activity against a persistent strain of Listeria monocytogenes isolated from Surubim. J. Food Prot., 68, 2068-2077.

2. De Martinis, E.C.P.; Duvall, R.E.; Hitchins, A.D. (2007). Real time PCR detection of $16 \mathrm{~S}$ rRNA genes speeds MPN enumeration of foodborne Listeria monocytogenes. J. Food Prot., 7, 1650-1656.

3. Destro. (2000). Incidence and significance of Listeria in fish and fish products from Latin America. Int. J. Food Microbiol., 62, 191-196.

4. FSIS. United States Department of Agriculture. Food Safety and Inspection Service. 2007. http://www.fsis.usda.gov/Fsis_Recalls/.

5. Ingianni, A.; Floris, M.; Palomba, P.; Madeddu, M.A.; Quartuccio, M.; Pompei, R. (2001). Rapid detection of Listeria monocytogenes in foods, by a combination of PCR and DNA probe. Mol. Cell. Probes, 15, 257-280.

6. Koch, J.; Stark, K. (2006). Significant increase of listeriosis in Germany - Epidemiological patterns 2001-2005. Euro Surveill., 11 (6), p. 85-88.

7. Lyytikäinen, O.; Nakari, U.M.; Lukinmaa, S.; Kela, E.; Nguyen Tran Minh, N.; Siitonen, A. (2006). Surveillance of listeriosis in Finland during 1995-2004. Euro Surveill., 11 (6), p. 82-85.

8. Pagotto, F.; Daley, E.; Farber, J. (2002). Enumeration of Listeria monocytogenes in food. Compendium of analytical methods, MFLP74, Canada.Health Products and Food Branch.

9. Peeler, J.T.; Houghtby, G.A.; Rainoser, P. (1992). The most probable number technique, p. 105-120. In: C. Vanderzant and D.F. Splittstoesser (ed.), Compendium of methods for the microbiological examination of foods, $3^{\text {rd }}$ ed. American Public Health Association, Washington D.C.

10. Ryser, E.T.; Donnelly, C.W. (2001) Listeria. In: Downes, F.P.; Ito, $\mathrm{K}$. (eds.). Compendium of methods for the microbiological examination of foods: American Public Health Association, Washington D.C., USA, p. 343-356.

11. WHO and FAO - World Health Organization and Food and Agriculture Organization of the United Nations: Risk assessment of Listeria monocytogenes in ready-to-eat foods, MRA Series No. 4-5. 2004. http://www.who.int/foodsafety/publications/micro/mra_listeria/en/ index.html. 